\title{
Inoculation Effects of Rhizobium and Phosphorous Solubulizing Bacteria on Growth and Nodulation of Acacia nilotica
}

\author{
Rakesh Kumar, D. Dash", S.B. Gupta, R. Soni and Anup Ku. Singh \\ Department of Agricultural Microbiology, College of Agriculture, Indira Gandhi Krishi \\ Vishwabidyalaya, Raipur-492012, Chhattisgarh, India \\ *Corresponding author
}

\section{A B S T R A C T}

Keywords

Acacia nilotica,

Rhizobium, PSB,

Stress tolerance,

Biomass and

nodulation.

Article Info

Accepted:

21 September 2017

Available Online:

10 October 2017
A study was conducted in green house of Department of Agricultural Microbiology, College of Agriculture, Chhattisgarh during 2015-16 to study the effect of Rhizobium and Phosphorous Solubulizing Bacteria inoculation on growth performance of Acacia nilotica. The treatments were inorganic fertilization only, inoculation with Rhizobium, PSB alone and along with 25 per cent $\mathrm{N}$ including control. The Rhizobium isolate from nodule of $A$. nilotica was found good in its growth at $30^{\circ} \mathrm{C}$ and $6.5-7.5 \mathrm{pH}$ but showed tolerance up to $50^{\circ} \mathrm{C}$ and $\mathrm{pH} 5.5$ to 8. PSB isolate, isolated from rhizosphere zone of A. nilotica plant was found to survive at $\mathrm{pH} \mathrm{5}$, however $\mathrm{pH} 6$ to 7 was found most suitable for its growth. $A$. nilotica - PSB showed well growth at temperature $30^{\circ} \mathrm{C}$ and decreases with increasing temperature from $35^{\circ} \mathrm{C}$ to $50^{\circ} \mathrm{C}$. Dual inoculation of A. nilotica with Rhizobium and PSB along with addition of $25 \%$ nitrogen recorded significantly higher shoot length (78.75 $\mathrm{cm})$, root length $(53.75 \mathrm{~cm})$, collar diameter $(6.15 \mathrm{~mm})$ and shoot dry biomass accumulation $\left(7.66 \mathrm{~g} \mathrm{plant}^{-1}\right)$ over other treatments at 90 DAT. Significantly higher nodulation (38no. and dry weight of nodules $0.283 \mathrm{~g} \mathrm{plant}^{-1}$ ) also recorded with Rhizobium $+P S B+25 \% \mathrm{~N}$ at 60 DAT.

\section{Introduction}

Restoration and maintenance of soil fertility is a basic but critical ecological problem especially in the tropics where the soils are nutrient deficient particularly $\mathrm{P}$ and $\mathrm{N}$. The degraded soils are reclaimed through afforestation programmes with multifarious forest legume tree species along with beneficial microbes. Acacia nilotica, commonly known as Indian Gum-Arabic Tree and locally 'Babul' is one of the important Nitrogen Fixing Tree (NFT) species belongs to family Fabaceae, sub-family Mimosoideae. This species provides nutritious fodder for livestock, firewood for local people for daily needs and wood for a variety of purposes (Sarra et al., 2005). It is extensively planted in farm lands, wasteland, roadside avenues and is important for afforestation programme. Nitrogen and phosphorous are essential nutrient for plant growth and development. Use of inorganic fertilizers has led to worldwide ecological problems as well as affects the human health. However, biofertilizers offer an alternative to chemical inputs, which have an ability of mobilizing the nutrionally important elements from nonuseable to useable form and known to increase yield. Biofertilizer improve the 
quality of tree seedlings which are better adopted to withstand the adverse condition as bio-fertilizer has tremendous potential to provide plant nutrients by boosting in microbial population present in soil which in turn makes the insoluble nutrients available for growth of the plants (Kelel, 2014).

Hence for successful plantation in waste and degraded land, quality seedling stocks should be raised in nursery which necessitates the use of microbial inoculants further for $\mathrm{N}$ management in soil and to enhance biological $\mathrm{N}$ fixation, biofertilizer application contribute significantly. This type of study was also carried out by Totey et al., (2000), Krishnaveni (2010). Besides N fixing organisms, it is now established that the enhanced growth of plant is also due to absorption of ions especially $\mathrm{P}$ from the soil and subsequent transfer to plants (Rani et al., 1999). Inoculation of tree legume with PSB can stimulate the growth. The purpose of present investigation was to screen and identify the stress tolerant potential isolate for improvement of A. nilotica.

So considering these facts, to increase biomass productivity, seedling quality and to improve BNF of $A$. nilotica and to improve fertility of degraded land, there is need to adopt the eco-friendly management strategies which will be economically feasible. There were several previous reports dealing isolation, screening and application of beneficial microbes, either individually or combined, to assess their effects on the growth and biomass production of several trees (Bora et al., 2006; Kumar et al., 2013; Bhagat et al., 2014). Therefore, the present investigation was carried out to isolate and characterize the Rhizobium sp. from $A$. nilotica nodules and PSB from rhizosphere soils of $A$. nilotica and to assess the effect of these inoculants alone and in combination with nitrogen for improving growth and nodulation above all for the production of healthy seedling stocks.

\section{Materials and Methods}

A greenhouse pot experiment was conducted at Department of Agricultural Microbiology, Indira Gandhi Krishi Vishwavidyalaya, Raipur (Chhattisgarh) during 2015-2016 with Acacia nilotica. The experiment was laid out in complete randomized design (CRD) with 6 treatments replicated four times. Treatments in the experiment included $\mathrm{T}_{1}$-Control, $\mathrm{T}_{2}$ Inorganic Fertilization (N,P,K as 1.5:1:1g Urea, SSP, MOP per seedling), $\mathrm{T}_{3}$-Rhizobium Inoculation, $\mathrm{T}_{4}$-PSB Inoculation, $\mathrm{T}_{5^{-}}$ Rhizobium $+25 \% \mathrm{~N}, \mathrm{~T}_{6}$-Rhizobium $+\mathrm{PSB}+$ $25 \% \mathrm{~N}$. The Rhizobium strains isolated from A. nilotica nodules and PSB strain isolated from rhizosphere soils of A. nilotica were used for inoculation. For inorganic fertilization, Nitrogen, Phosphorus and Potassium were applied to polybags through Urea, SSP and MOP respectively in water soluble form to the soil in polybag before transplantation in as per treatment.

\section{Isolation, screening and inoculum preparation}

Rhizobium was isolated from fresh nodule of collected Acacia nilotica (Babul) seedling naturally grown in the nearby Agriculture College campus and pure culture was identified by streaking selected colonies on the YEMA (Yeast Extract Mannitol Agar) media. The isolated Rhizobium was multiplied and a single discrete colony was transferred to YEMA slant to maintain the isolate (Vincent, 1970). Culture broth was prepared using YEM Yeast Extract Mannitol).

Soil samples were collected to a depth of $30 \mathrm{~cm}$ from rhizosphere soil from Acacia nilotica grown in different locations of District, Chhattisgarh during January, 2015 
for the purpose of isolation of PSB from collected soil samples (Table 1). The appearance of clearing zone around bacterial colonies after $96 \mathrm{~h}$ of growth at $30^{\circ} \mathrm{C}$ was used as indicator for positive Phosphorus solubilization.

\section{Preparation of inoculums}

To prepare the culture suspension for experimentation, the isolate Acacia nilotica Rhizobium and PSB were inoculated in sterilized YEM broth and Pikovaskya's broth in conical flask incubated respectively at $\mathrm{pH}$ (7.0) and temperature at $28 \pm 2^{0} \mathrm{C}$ for 48 hours and then were kept on a rotary shaker for 7 days. These cultures were then used for inoculation treatment.

\section{Characterization of isolates}

\section{Gram staining and colony morphology}

Acacia nilotica -Rhizobium and PSB isolates were activated by inoculating in YEM and Pikovskaya's media respectively of $\mathrm{pH}$ (7.0) and temperature $\left(28^{\circ} \mathrm{C}\right)$ and characterized for Gram staining, colony morphology (Aneja, 2003).

\section{Assessment of acidity and temperature tolerance potency of isolates}

For acidity tolerance, the $\mathrm{pH}$ level of YEM broth was adjusted by $\mathrm{HCl} / \mathrm{NaOH}$ and then inoculated with species Rhizobium isolate. After completion of 3 days incubation period survival of Rhizobium were recorded. The effect of $\mathrm{pH}$ on PSB isolates was determined by inoculating isolates on Pikovskaya's agar plates, the $\mathrm{pH}$ level of broth was adjusted by $\mathrm{HCl} / \mathrm{NaOH}$. After completion of 3 days incubation period survival of PSB were observed for the halo zone formation.

YEM broth inoculated with Acacia nilotica Rhizobium isolate were subjected to different temperatures $30-55^{\circ} \mathrm{C}$ for 30 minutes in water bath. After thermal shocks, broth cultures were cooled down to room temperature and isolate was inoculated into petriplates containing specific medium with 4 replications. All the inoculated petriplates were incubated in incubator at $28 \pm 2^{0} \mathrm{C}$ for 2 6 days (Benson, 1990). Observations were recorded for survival and/or growth of inoculums. The effect of temperature on phosphate solubilizing ability of selected phosphate solubilizing isolates was determined by placing PVK broth tubes containing 3-4 days old inoculated bacterial culture in water bath and exposed to $30^{\circ} \mathrm{C}$ $55^{\circ} \mathrm{C}$. These bacterial cultures were then spot inoculated on plates containing PVK medium and further observed for clear zone formation by them.

Sample collection, experimental site, transplantation, observation and statistical analysis

Soils were randomly collected from a depth of $(15 \mathrm{~cm})$ from soil surface from agricultural fields and thoroughly mixed to form a composite sample. A well mixed $5 \mathrm{Kg}$ mixture of soil, sand and compost in 3:1:1 ratio was filled in each polythene bag (12"x 10 " size). The soil of the experimental site was vertisol having $\mathrm{pH} 7.6$, organic carbon $6.3 \mathrm{~g} / \mathrm{kg}$ soil, mineralizable Nitrogen status (204.4 kg/ ha.), low in available (Olsen's) Phosphorus content $(11.6 \mathrm{~kg} / \mathrm{ha}$.) but higher in status with respect to available Potassium content (416 kg/ha.). The analysis was done as per Page et al., (1982).

Seeds of Acacia nilotica were collected from naturally grown area of A. nilotica and were allowed to germinate by soaking in water for half an hour and then sown in trays containing field soil and sand (2:1). Uniform size seedlings of 15 days old were selected for experiment purpose. Experimental site Raipur is situated in plains of Chhattisgarh at $21^{\circ} 16^{\prime}$ 
$\mathrm{N}$ latitude and $81^{0} 36^{\prime}$ E longitude with an altitude of 289.60 meter above mean sea level (MSL). Seedlings were inoculated with matured broth of Rhizobium and PSB prior to transplantation as per treatments and were allowed to grow up to 3 months /90 Days. In uninoculated pots, seedlings were dipped in same amount of nutrient broth but not inoculated with Rhizobium and PSB. Observations were taken at 30 days interval up to 90 DAT of A. nilotica plant. Morphological growth parameters viz., Shoot length, Root length, Collar Diameter of Acacia nilotica seedlings were recorded at 30 days intervals after transplant. Also nodulation behaviour in Acacia nilotica plants at different stages of transplanting was recorded. The dry weight was recorded after drying in the hot air oven at $70^{\circ} \mathrm{C}$ to constant weight. All observations were statistically analyzed using ANOVA for CRD. The significant differences were tested through $\mathrm{F}$ test at 5\% level of significance (Panse and Sukhatme, 1978).

\section{Results and Discussion}

Isolation and colony morphology of Acacia nilotica - Rhizobium and phosphate solubilizing bacteria

A. nilotica- Rhizobium (isolated from nodule of locally grown nodulated A. nilotica plant. On YEMA media Rhizobium isolate produced translucent, nearly round and gummy colonies which were Convex in elevation having nearly entire margin varied in size between 1.5 to $2.00 \mathrm{~mm}$ (Table 1). After the gramstaining the bacteria assumed a red colour which indicated that it was Gram -ve. Native PSB isolate required for the study was screened from 11 isolates, isolated from rhizospheric soils of $A$. nilotica tree commonly grown in different locations of two districts, $\quad \operatorname{Raipur}\left(22.35^{\circ} \mathrm{N} \quad 82.68^{\circ} \mathrm{E}\right)$ and Mungeli $\left(22.40^{\circ} \mathrm{N} 81.40^{\circ} \mathrm{E}\right)$ of Chhattishgarh on the basis of their qualitative phosphate soubilization and stress tolerant character. (Tables 1 and 2) Soil sample of known amount were allowed to grow in PVK broth containing $0.05 \mathrm{~g}$ tri calcium phosphate in each test tubes in incubator cum shaker at $30^{\circ} \mathrm{C}$ temp for 7 days. After efficient growth of microbes in tubes they were streaked on a plate containing PVK agar. The selection of PSB was made after screening the bacterial colonies developed on plates for their morphological similarities to Bacillus and Pseudomonas genera, as it was reported by Komy (2005). This work is in line with Krishnaveni (2010). Native PSB isolates from 11soil samples were further grow on the Pikovskaya's agar (PKV) plates, out of which only 4 isolates were found capable of forming a clear zone on solid media Pikovskaya. The isolation studies of PSB are in co-ordination with the work done by Krishnaveni (2010) and Kelel (2014). Out of 11 PSB isolates, isolates namely PSB-1, PSB-2, PSB-5 and PSB-10 were found forming clearing zone. Colonies of all the isolates were found to be round and yellowish in colour. All the isolates were gram negative (Table 1).

Selected isolates were identified based on staining, morphological, cultural and biochemical tests according to Bergey's Manual of Systematic Bacteriology and were found belonged to Pseudomonas genera. The isolate PSB-2 was observed better growth and clearing zone as compared to other three PSB isolates. The efficacy of $\mathrm{P}$ solubilization by individual isolate on agar medium revealed that PSB formed clear zones by solubilising suspended tri-calcium phosphate.

Traditionally, the clearing/halo zone around the colony is used as an indicator for $\mathrm{P}$ solubilization. Malboobi et al., (2009) found that the active growth of bacteria correlates well with $\mathrm{P}$ solubilization; hence the colony growth diameter of the PSB should be viewed merely as a first indication of the $\mathrm{P}$ solubilization potential only. 
Acidity and temperature tolerance behavior

Rhizobium isolate of Acacia nilotica was observed as potent acidity tolerant isolates and survive as low as $\mathrm{pH} 5$. But $\mathrm{pH} 6$ to 7 was found most suitable $\mathrm{pH}$ for its growth and shows survivality upto $\mathrm{pH} 8$ (Table 2). Segura (1995) observed 5 strains of Rhizobium out of 50 screened to be tolerant to acidity up to $\mathrm{pH}$ 4.5 and 5 in liquid and solid culture. Mpepereki et al., (1997), however observed growth of lathyrus-Rhizobium upto even upto $\mathrm{pH}$ 4. Acacia nilotica - Rhizobium can grow well at temperature $30^{\circ} \mathrm{C}$ and $35^{\circ} \mathrm{C}$ while with increase in temperature growth reduces, but it can also tolerate upto $50^{\circ} \mathrm{C}$ temperature. It shows minimum growth at $50{ }^{\circ} \mathrm{C}$ (Table 2 ).

A total of 04 bacterial isolates (PSB-1, PSB-2, PSB-5 and PSB-10) capable of forming a clear zone on solid media Pikovskaya were studied for phosphate solubilization ability under stress conditions. The effect of $\mathrm{pH}$ on phosphate solubilisation was tested by growing strains on $\mathrm{PVK}$ medium of which $\mathrm{pH}$ was adjusted (from 5 to 8.0) using $\mathrm{HCl}$ and $\mathrm{NaOH}$, the isolate PSB-2 has shown solubilization zone in plate assay and good colony growth. PSB isolate of Acacia nilotica was the most potent acidity tolerant isolates and survive as low as $\mathrm{pH} 5 . \mathrm{pH} 6$ to 7 was found most suitable $\mathrm{pH}$ for its growth and shows survivelity upto $\mathrm{pH} 8$ (Table 2).

Similarly to assess the effect of high temperature, these isolates were kept at 30 to $60{ }^{\circ} \mathrm{C}$ temperature for 30 minutes and then after allowed to grow on PVK plates. Acacia nilotica - PSB shows full growth at temperature $30{ }^{0} \mathrm{C}$. Growth decreases while increasing temperature from $35^{\circ} \mathrm{C}$ to $55^{\circ} \mathrm{C}$. It shows minimum growth at $55^{\circ} \mathrm{C}$. PSB-2 isolates out of 04 isolates was efficient to form solubilization zone. PSB-2 isolates was selected for inoculation purpose as it was found to be potential phosphate solubilizers and stress tolerant (Table 2).

Kelel (2014) studied that PSB colonies isolated from the Acacia plant rhizophere soil demonstrated high phosphate liberating activity and survived at temperatures to $47^{\circ} \mathrm{C}$ over a $\mathrm{pH}$ range of 4.5 to 8.5. These results provide a strong baseline source for application in agriculture when a bio-fertilizer is required. Surange et al., (1997) also characterized Rhizobium from root nodules of leguminous trees. Identification of stress tolerant crop beneficial microbes is certainly useful in order to formulate those cultures which are able to survive / persist for longer period and work more efficiently under climatic conditions o Chhattishgarh Plains.

Fig.1 Effect of Rhizobium and PSB inoculation on nodule no and nodule dry weight in A. nilotica

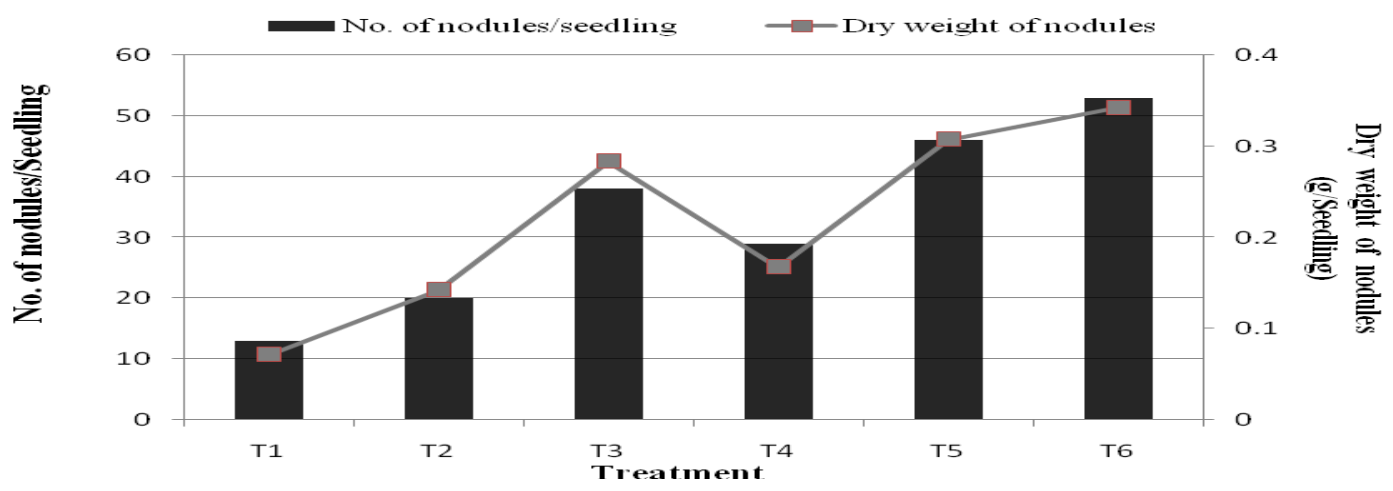


Table.1 Isolation and colony characterization of native Rhizobium and PSB isolates for A. nilotica

\begin{tabular}{|c|c|c|c|c|c|c|}
\hline \multicolumn{3}{|c|}{ Locations } & \multirow[t]{2}{*}{ Isolates } & \multirow{2}{*}{$\begin{array}{l}\text { Colony } \\
\text { growth }\end{array}$} & \multirow{2}{*}{$\begin{array}{c}\text { Gram } \\
\text { staining }\end{array}$} & \multirow[t]{2}{*}{ Colony morphology } \\
\hline District & Block & Village & & & & \\
\hline \multicolumn{7}{|c|}{ Isolation of Rhizobium } \\
\hline Raipur & Dharsiva & Jora & $\begin{array}{l}\text { A. nilotica- } \\
\text { Rhizobium }\end{array}$ & +++ & -ve & $\begin{array}{c}\text { Forming Round, White } \\
\text { translucent, Nearly Entire } \\
\text { margin, Convex (slightly flat) } \\
\text { Smooth colony on YEMA } \\
\text { medium }\end{array}$ \\
\hline \multicolumn{7}{|c|}{ PSB isolates forming colony growth on PKV medium } \\
\hline \multirow[t]{9}{*}{ Mungeli } & \multirow[t]{3}{*}{ Mungeli } & Sangwakapa & PSB-1 & ++ & -ve & $\begin{array}{c}\text { Smooth, round and Yellowish, } \\
\text { Showing clearing zone }\end{array}$ \\
\hline & & Devrikhurd & PSB-2 & +++ & -ve & $\begin{array}{l}\text { Smooth, round and Yellowish, } \\
\text { Showing clearing zone }\end{array}$ \\
\hline & & Kodvabani & PSB-3 & + & -ve & Not forming clearing zone \\
\hline & \multirow[t]{3}{*}{ Lormi } & Dumraha & PSB-4 & + & -ve & Not forming clearing zone \\
\hline & & Chilfi & PSB-5 & ++ & -ve & $\begin{array}{c}\text { Smooth, round and Yellowish, } \\
\text { Showing clearing zone }\end{array}$ \\
\hline & & Sahaspur & PSB-6 & + & -ve & Not forming clearing zone \\
\hline & \multirow[t]{3}{*}{ Pathriya } & Pathriya & PSB-7 & + & -ve & Not forming clearing zone \\
\hline & & Dharmpura & PSB-8 & + & -ve & Not forming clearing zone \\
\hline & & Bhaisatrai & PSB-9 & + & -ve & Not forming clearing zone \\
\hline \multirow[t]{2}{*}{ Raipur } & \multirow[t]{2}{*}{ Rajim } & Rajim & PSB-10 & ++ & -ve & $\begin{array}{c}\text { Smooth, round and Yellowish, } \\
\text { Showing clearing zone }\end{array}$ \\
\hline & & Navapara & PSB-11 & + & -ve & Not forming clearing zone \\
\hline
\end{tabular}

Table.2 Acidity and thermal tolerance behavior

\begin{tabular}{|c|c|c|c|c|c|c|c|c|}
\hline & \multicolumn{8}{|c|}{ Growth in different pH } \\
\hline & $5.0 \mathrm{pH}$ & $5.5 \mathrm{pH}$ & $6.0 \mathrm{pH}$ & $6.5 \mathrm{pH}$ & $7.0 \mathrm{pH}$ & $7.5 \mathrm{pH}$ & $8.0 \mathrm{pH}$ & Control \\
\hline \multicolumn{9}{|c|}{ selected PSB isolates } \\
\hline PSB-1 & + & + & ++ & ++ & ++ & ++ & + & ++ \\
\hline PSB-2 & + & +++ & +++ & +++ & +++ & +++ & + & +++ \\
\hline PSB-5 & + & + & ++ & ++ & ++ & ++ & + & ++ \\
\hline PSB-10 & + & + & ++ & ++ & ++ & ++ & + & ++ \\
\hline \multicolumn{9}{|c|}{ Growth behavior of Acacia nilotica - Rhizobium isolate in YEMA of different pH } \\
\hline & ++ & ++ & +++ & +++ & +++ & ++ & + & +++ \\
\hline & \multicolumn{8}{|c|}{$\begin{array}{l}\text { Growth in PVK medium after subjected to thermal shock at different temperature for } 30 \\
\text { minutes }\end{array}$} \\
\hline & $30{ }^{0} \mathrm{C}$ & $35^{0} \mathrm{C}$ & $40^{0} \mathrm{C}$ & $45^{\circ} \mathrm{C}$ & $50{ }^{0} \mathrm{C}$ & $55^{0} \mathrm{C}$ & $60^{0} \mathrm{C}$ & Control \\
\hline PSB-1 & ++ & ++ & ++ & ++ & + & - & - & ++ \\
\hline PSB-2 & +++ & +++ & +++ & +++ & + & + & - & +++ \\
\hline PSB-5 & ++ & ++ & ++ & ++ & + & - & - & ++ \\
\hline PSB-10 & ++ & ++ & ++ & ++ & + & + & & ++ \\
\hline \multicolumn{9}{|c|}{$\begin{array}{l}\text { Growth in YEMA medium after subjected to thermal shock at different temperature for } 30 \text { minutes Growth behavior o } \\
\text { isolate }\end{array}$} \\
\hline A.nilotica - Rhizobium & +++ & +++ & ++ & \begin{tabular}{l|l}
+++ \\
\end{tabular} & + & - & - & +++ \\
\hline
\end{tabular}


Table.3 Inoculation effects on growth parameters of Acacia nilotica at 90 Days after transplant

\begin{tabular}{|l|l|l|l|}
\hline \multirow{2}{*}{ Treatments } & \multicolumn{3}{|c|}{ Morphological growth parameters } \\
\cline { 2 - 4 } & Shoot length $(\mathbf{c m})$ & Root length $(\mathbf{c m})$ & Collar Diameter $(\mathbf{m m})$ \\
\hline T1 & 58.50 & 36.50 & 5.05 \\
\hline T2 & 63.00 & 41.75 & 5.25 \\
\hline T3 & 76.00 & 44.50 & 5.73 \\
\hline T4 & 69.25 & 48.75 & 5.45 \\
\hline T5 & 77.25 & 46.50 & 5.85 \\
\hline T6 & 78.75 & 53.75 & 6.15 \\
\hline SEm $( \pm)$ & 1.39 & 0.78 & 0.10 \\
\hline CD $(\mathbf{5 \% )}$ & 4.13 & 2.30 & 0.30 \\
\hline
\end{tabular}

$T_{1}$-Control $T_{2}$-Inorganic Fertilization $T_{3}$-Rhizobium Inoculation, $T_{4}$-PSB Inoculation, $T_{5}$-Rhizobium $+25 \% ~ N, T_{6^{-}}$ Rhizobium + PSB $+25 \%$

Table.4 Inoculation effects on nodulation behavior of Acacia nilotica plants

\begin{tabular}{|c|c|c|c|c|c|c|}
\hline \multirow[t]{3}{*}{ Treatment } & \multicolumn{2}{|c|}{$\begin{array}{l}\text { No. } \\
\text { nodules/seedling }\end{array}$} & \multicolumn{2}{|c|}{$\begin{array}{l}\text { Fresh weight of } \\
\text { nodules (g/seedling) }\end{array}$} & \multicolumn{2}{|c|}{$\begin{array}{l}\text { Dry weight of nodules } \\
\text { (g/seedling) }\end{array}$} \\
\hline & \multicolumn{2}{|c|}{ Days after transplant } & \multicolumn{2}{|c|}{ Days after transplant } & \multicolumn{2}{|c|}{ Days after transplant } \\
\hline & 60 & 90 & 60 & 90 & 60 & 90 \\
\hline T1 & 13.00 & 6.00 & 0.41 & 0.11 & 0.071 & 0.002 \\
\hline $\mathbf{T 2}$ & 20.00 & 8.00 & 1.18 & 0.21 & 0.142 & 0.004 \\
\hline T3 & 38.00 & 16.00 & 1.32 & 0.69 & 0.283 & 0.074 \\
\hline T4 & 29.00 & 12.00 & 1.22 & 0.32 & 0.167 & 0.052 \\
\hline T5 & 46.00 & 20.00 & 1.41 & 0.92 & 0.307 & 0.076 \\
\hline T6 & 53.00 & 22.00 & 1.52 & 1.14 & 0.342 & 0.088 \\
\hline SEm $( \pm)$ & 1.21 & 0.88 & 0.05 & 0.03 & 0.01 & 0.01 \\
\hline CD (5\%) & 3.61 & 2.62 & 0.15 & 0.08 & 0.03 & 0.02 \\
\hline
\end{tabular}

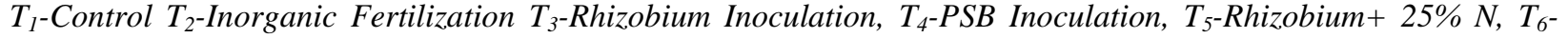
Rhizobium + PSB $+25 \%$

Rhizobium and PSB inoculation effects on growth parameters of Acacia nilotica

Results on morphological growth parameters of Acacia nilotica plants treated with different treatments are presented in (Table 3) Dual inoculation along with less $\mathrm{N}$ dose significantly influenced the growth of $A$. nilotica followed by Rhizobium inoculation along with less $\mathrm{N}$ dose.

Shoot length increased by 1.35 and 1.32 times over control with Rhizobium + PSB $+25 \% \mathrm{~N}$ (T6) and Rhizobium inoculation along with
$25 \% \mathrm{~N}$ (T5) treatments respectively at 90DAT. Significantly highest shoot length $(78.75 \mathrm{~cm})$ was found in $\mathrm{T} 6$ followed by $77.25 \mathrm{~cm}$ in T5 and $76.00 \mathrm{~cm}$ in T3 at 90 DAT. In Inorganic Fertilization, shoot length was found $(63.00 \mathrm{~cm})$ whereas at $\mathrm{T} 1$ it was $58.50 \mathrm{~cm}$.

However effect of Rhizobium inoculation was significant with respect to shoot length as compared to only PSB inoculation, inorganic fertilizer treatment and control, but T3, T5 and T6 were at par. Totey et al., 2000 observed application of $5 \mathrm{ml}$ Rhizobium broth 
per plant to $A$. procera increased the relative height of 1 year old plantation by 1.2 times over control.

Dual inoculation of Rhizobium and PSB along with $25 \% \mathrm{~N}$ dose significantly influenced the root growth of Acacia nilotica increasing root length by 1.47 times over control. Significantly highest root length $(53.75 \mathrm{~cm})$ was found in $\mathrm{T} 6$ followed by $48.75 \mathrm{~cm}$ in $\mathrm{T} 4$, $46.50 \mathrm{~cm}$ in $\mathrm{T} 5$ and $44.50 \mathrm{~cm}$ in $\mathrm{T} 3$ whereas at $\mathrm{T} 1$ it was $36.50 \mathrm{~cm}$ at 90 DAT. Inoculated Acacia nilotica plants showed significantly higher root length ranging from 44.50 to $53.75 \mathrm{~cm}$, at 90 DAT as compared to control and uninoculated ones in which root length were 36.5 to $41.75 \mathrm{~cm}$ at 90 DAT respectively under $\mathrm{T}_{1}$ and $\mathrm{T}_{2}$. It is evident from data that collar diameter of Acacia nilotica plants also showed significant effect in dual inoculated treatments over singly inoculation and uninoculated seedlings being maximum $(6.15 \mathrm{~mm})$ at $\mathrm{T} 6$ followed by $(5.85 \mathrm{~mm})$ at $\mathrm{T} 5$, $5.73 \mathrm{~mm}$ at $\mathrm{T} 3$ and $5.45 \mathrm{~mm}$ at $\mathrm{T} 4$ while minimum $(5.05 \mathrm{~mm})$ at control at 90 DAT. However inoculation of seedlings alone and along with $\mathrm{N}$ was found significant for collar diameter in Acacia nilotica plants. But the treatments $\mathrm{T}_{1}$ and $\mathrm{T}_{2}$ were at par (Table 3 ).

Totey et al., (1997) found that with application of Rhizobium biofertilizer which is specific to $D$. sissoo only on growth of 3 weeks old seedling of $D$. sissoo remarkable increase in growth. Biofertilizer helps boost microbial population present in soil which in turn makes the insoluble nutrients available for growth of plant. Similar observations were also found by Chauhan and Pokhriyal (2002) in Albizzia. Similar observations were also found by Chauhan and Pokhriyal (2002) in Albizzia and Kumar et al., (2013) in D. sissoo. Inoculated seedlings significantly showed higher shoot length, root length and collar diameter as compared to uninoculated ones (inorganic $\mathrm{N}$ fertilization and control).
Among inoculated treatments, Rhizobium and PSB inoculation along with $\mathrm{N}$ affected much followed by Rhizobium $+\mathrm{N}$ treated seedlings.

\section{Rhizobium and PSB Inoculation effects on nodulation behaviour of Acacia nilotica}

The nodular properties like nodule no., nodule fresh weight and nodule dry weight as affected by different treatments and different age of seedlings are presented in (Table 4 and Fig. 1). The no. of nodules per seedling ranged from 6 to 53 under different treatments and at different ages of seedlings. With Rhizobium inoculation +PSB with $25 \% \mathrm{~N}$ significantly maximum average nodule no./seedlings was 53.00 followed by only with Rhizobium with $25 \% \quad N$ (38 nodule no./seedlings) whereas very sparse nodulation (13) was seen in control at 60 DAT. With Rhizobium inoculation nodules number increase to 38/seedling and further increased to 46 and 53 due to starter dose of $\mathrm{N}$ and PSB inoculation along with Rhizobium. Acacia nilotica nodules were irregular in shape, elongated and somewhat medium to big size nodules (Table 4) (Fig. 1).

Similar trend was observed in case of nodule fresh weight and nodule dry weight. The effect of dual inoculation along $25 \%$ of $\mathrm{N}$ was significant over only Rhizobium inoculation alone. The fresh weight of nodules varied from 0.11 to $1.52 \mathrm{~g} / \mathrm{seedling}$ under different treatments at various growth stages of Acacia nilotica plant. At 60 DAT significantly maximum nodule dry weight (g/ seedling), 0.342 was found at T6 followed by 0.307 at $\mathrm{T} 5,0.283$ at $\mathrm{T} 3$ and 0.167 at $\mathrm{T} 4$ while at control it was minimum (0.071).

Inoculation of A. nilotica with its specific Rhizobium and PSB could bring out an amazing effect so far nodulation, growth and dry matter production of these legumes are concerned. This is an agreement with the 
report made earlier by Bora et al., (2006). The magnitude of these data showed that inoculation with Rhizobium alone and along with PSB significantly influenced the nodular properties at different stages of the seedling.

The present findings showed that both Rhizobium and PSB application alone and along with $\mathrm{N}$ is comparatively better for improving growth and development of legume seedling i.e. A. nilotica as it influences other process such as photosynthesis, uptake of trace element and plant hormones along with nodulation and $\mathrm{N}$ fixation. Dual inoculation with Rhizobium and PSB treatments were highly significant w.r.t. growth parameters and nodulation in Acacia nilotica seedlings as compared to other treatments. Due to inoculation in Acacia nilotica shoot length increased from 58.50 to $78.75 \mathrm{~cm}$, collar diameter from 5.05 to $6.15 \mathrm{~mm}$ and Nodulation increased 0.071to 0.342 g/seedling. As compared to T4, PSB inoculation, significant effect was obtained at T6 ( R+ PSB $+25 \% \mathrm{~N})$ showing maximum nodule no. and dry weight i.e. 53/seedling and $0.342 /$ seedling respectively. Co-inoculation of Acacia nilotica with Rhizobium+PSB along with application of less $\mathrm{N}$ dose (25\% of RD) was found significantly effective in increasing the morphological growth and nodulation. This work is strongly supported by Moroque et al., (2002), Mahanty et al., (2004), Krishnaveni (2010), Kelel (2014). This type of study was also carried out by Bora et al., in year 2006 in $A$. procera who studied the combined effect of Rhizobium inoculation along with application of different levels of $\mathrm{N}$ dosages of fertilizer, observed both root and shoot biomass was considerably high in $A$. procera inoculation seedling growth and in LLU (low level urea).

Based on the results obtained in the present investigation, it can be concluded that dual inoculation with Rhizobium and PSB along with application of $25 \% \mathrm{~N}$ was significant in improving initial growth response of Acacia nilotica plants in nursery enhancing BNF. This finding may be helpful in producing quality planting stock of Acacia nilotica for afforestation programmes for the purpose of wasteland management.

The study further suggests that as NFT species are of great importance in traditional agro-forestry system, the detailed field investigation is recommended to ensure the long term growth performance of selected NFTs species in response of inoculation and $\mathrm{N}$ fertilizer application in natural stands. Improvement in seedling quality is essential for the survival of seedlings in degraded areas of low soil fertility and biological activity.

\section{References}

Aneja, K. R., 2003. Gram staining of bacteria. Experiments in Microbiology, Plant Pathology and Biotechnology. New Age International (P) Ltd. New Delhi. pp. 102105.

Benson, H.J., 1990. Temperature: Lethal effects. In Microbiological applications. Wm. C. Brown Publisher, USA. pp 125-126.

Bhagat, P. K., Dash, D., Raj, A. and Jhariya, M. K. 2014. Effect of Rhizobium inoculation on Growth and Biomass accumulation in Leucaena leucocephala. The Ecoscan: An International Quarterly J. of Environmental Sciences. 5, 65-74.

Bora, I.P., Baruah, A. and Singh, J. 2006. Effect of Rhizobium inoculation and nitrogen fertilizer application on seedling growth on Albizia procera (Robx.) benth. Indian Forester, 868-877.

Chauhan, S.K., and Sharma, R. 1997. Seedling quality evaluation: Importance in afforestation. Advances in Forestry Research in India. 17, 59-72.

Chouhan, Y.S., and Pokhriyal 2002. Effect of nitrogen and Rhizobium inoculation treatments on some growth parameters in Albizia lebbek (L). benth seedling. Indian Forester, pp. 316-321 
Kelel, M., 2014. Isolation of phosphate solubilizing bacteria from acacia tree rhizophere soil Journal of Microbiology and Biotechnology Research. $2231-3168$.

Komy, M.A.H., 2005. Co immobilization of Azospirillum lipoferum, Bacillus megaterium for Successful Phosphorus, Nitrogen Nutrition of Wheat Plants. Food Technol. Biotechnol. 43 (1), 19-27.

Krishnaveni, M.S., 2010. Studies on Phosphate Solubilizing Bacteria (PSB) in Rhizosphere and Non-Rhizosphere Soils in Different Varieties of Foxtail Millet (Setaria italica) International Journal of Agriculture and Food Science Technology.1 (1), pp. 23-39.

Kumar, A., Dash, D. and Jhariya, M. K. 2013. Impact of Rhizobium on growth, biomass accumulation and nodulation in Dalbergia sissoo. The BioScan, an International Journal of Life Science. 8(2), 553-560.

Malboobi, M. A., Owlia, P., Bebhabani, M., Sarokhani, E., Moradi, S., Yakhcali, B., Deljou, A. and Heravi, K. M. 2009. Solubilization of organic and inorganic phosphates by three highly efficient soil bacterial isolates. World J. Microbiol.Biotechnol., 25, 1471-1477.

Mohanty, S., Das, P.K. and Mohanty, A.K. 2004. Effect of microbial inoculation of growth and biomass production of Sissoo (Dalbergia sissoo). Journal of Interacademicia, 8(1), 11-16.

Morques, M.S., Pafano, M. and Scotti, M.R.M.M.L. 2002. Dule inoculation of wood legume (Cntroloium tomentosum) with Rhizobia and Mycorrhizal fungi in southeastern Brazil. Agroforestry System, 52, 107-117.

Mpepereki, S., Makonese, F. and Wollum, A.G. 1997. Physiological characterization of indigenous rhizobia nodulating Vigna unguiculata in Zimbabwean Soils. Symbiosis-Rehovot, 22, 275-292.
Page, A.L., Millar, R.H. and Keeny, D.R. 1982. Methods of soil analysis, part-2. Chemical and Microbiological properties. 2nd edition no. (9) part-2 in the serirs.

Panse, V.G., and Shukhatme, P.V. 1978. Statistical Methods for Agricultural Workers.Indian Council of Agricultural Research. New Delhi. 145-156.

Rani, P., Aggarwal, A. and Mehrotra, R.S. 1999. Growth responses in Acacia nilotica inoculated with VAM fungi (Glomus mosseae), Rhizobium sp. and Trichoderma harzianum. Indian Phytopath. 52 (2), 151153.

Sarr, A., Diop, B., Peltier, R., Neyra, $\mathrm{M}$ and Lesueur, D. 2005. Effect of rhizobial inoculation methods and host plant provenances on nodulation and growth of Acacia senegal and Acacia nilotica. New Forests. 29, 75-87.

Segura, R.C., 1995. Selecting in vitro of Rhizobium for tolerance to acidity and aluminium. Agronomia-Colombiana. 12, 142-148.

Surange, S., Wollum, N. and Nautiyal, C.S. 1997. Characterization of Rhizobium from root nodules of leguminous trees growing in alkaline soils. Canadian Microbio.43 (9), 891-894.

Totey, N.G., Verma, R.K., Verghess, M., Shadangi, D.K., Khatri, P.K. and Pathak, H. D. 2000. Effect of (Rhizobium) Biofertilizers and varying levels of phosphorus on the growth of forest legumes. (D. sissoo \& Albizia procera). Indian journal of forestry, 23(2), 205-207.

Vincent, J.M., 1970. A manual for the practical study of root nodule bacteria. IBP Handbook No. 15, Blackwell Scientific Publications, Oxford. 14-15.

\section{How to cite this article:}

Rakesh Kumar, D. Dash, S.B. Gupta, R. Soni and Anup Ku. Singh. 2017. Inoculation Effects of Rhizobium and Phosphorous Solubulizing Bacteria on Growth and Nodulation of Acacia nilotica. Int.J.Curr.Microbiol.App.Sci. 6(10): 2444-2453.

doi: https://doi.org/10.20546/ijcmas.2017.610.289 